\title{
Redescription of Flexophora ophidii Prost \& Euzet, 1962 (Monogenea: Diclidophoridae) from Ophidion barbatum (Ophidiidae) off the Algerian coast, Mediterranean Sea
}

\author{
Chahinez Bouguerche $(\mathbb{D}) \cdot$ Jean-Lou Justine $\mathbb{D} \cdot$ Fadila Tazerouti $\mathbb{B}$
}

Received: 29 May 2020/ Accepted: 19 October 2020/Published online: 7 November 2020

(C) Springer Nature B.V. 2020

\begin{abstract}
The diclidophorid Flexophora ophidii Prost \& Euzet, 1962, the type- and only species of the genus Flexophora Prost \& Euzet, 1962, has never been redescribed neither reported since its original description. The latest lacked a diagnosis of the genus that remains unavailable to date. Flexophora ophidii is redescribed and illustrated based on examination of new material from the type-host Ophidion barbatum L. (Ophidiiformes: Ophidiidae) collected off the Algerian coast (new geographical record), southern Mediterranean. A diagnosis of the genus is provided.
\end{abstract}

\section{Introduction}

The Diclidophoridae Cerfontaine, 1895 is a cosmopolitan family of polyopisthocotyleans, infecting

This article is part of the Topical Collection Monogenea.

C. Bouguerche $(\bowtie) \cdot F$. Tazerouti

Laboratoire de Biodiversité et Environnement:

Interactions - Génomes, Faculté des Sciences

Biologiques, Université des Sciences et de la Technologie

Houari Boumediene, BP 32, El Alia Bab Ezzouar, Alger,

Algérie

e-mail: chahinezbouguerche@gmail.com

J.-L. Justine

Institut Systématique Évolution Biodiversité (ISYEB),

Muséum National d'Histoire Naturelle, CNRS, Sorbonne Université, EPHE, Université des Antilles, 57 rue Cuvier, CP 51, 75005 Paris, France gills, operculum and gill cavity of teleosts and elasmobranchs. To date, 53 nominate genera are assigned to this family (WoRMS, 2020) with 15 genera belonging to the subfamily Diclidophorinae Cerfontaine, 1895 (Cruces et al., 2017): Diclidophora Krøyer, 1838; Diclidophoroides Price, 1943; Osphyobothrus Yamaguti, 1958; Flexophora Prost \& Euzet, 1962; Allotagia Dillon \& Hargis, 1965; Upenicola Unnithan, 1966; Lebboia Mamaev \& Parukhin, 1975; Polyipnicola Mamaev \& Parukhin, 1975; Tribuliphorus Mamaev \& Parukhin, 1977; Inbjumia Mamaev \& Parukhin, 1984; Mamaevicotyle Lamothe-Argumedo, 1984; Campechia Zhukov \& Mamaev, 1985; Lampanyctophilus Payne, 1986; Mamaevodiclidophora Rubec, 1991 and Macrouridophora Rubec \& Dronen, 1994 (see Krøyer, 1838; Price, 1943; Yamaguti, 1958; Prost \& Euzet, 1962; Dillon \& Hargis, 1965; Unnithan, 1966; Payne, 1986; Rubec \& Dronen 1994; Rubec, 1991; Zhukov \& Mamaev, 1985; Mamaev et al., 1985; Rohde \& Williams, 1987).

Among the Diclidophorinae, Flexophora Prost \& Euzet, 1962 was erected to accommodate Flexophora ophidii Prost \& Euzet, 1962, from gills of the snake blenny Ophidion barbatum L. off France, northern Mediterranean (Prost \& Euzet, 1962). Flexophora and its type- and only species, $F$. ophidii, remains poorly known. Limited references to the genus were made in the literature, including in the descriptions of new genera (Zhukov \& Mamaev, 1985; Cruces et al., 2017; Mamaev, 1976; Payne, 1986) and a checklist (Euzet 
et al., 1993). The only existing record of the species and the genus is that of the original description, that unfortunately omitted a diagnosis of the genus.

In the course of a parasitological survey of helminths of fishes off the Southern coast of the Mediterranean Sea (Ayadi et al., 2017; Derouiche et al., 2019; Moravec et al., 2016; Chaabane et al., 2015; 2016a, 2016b; Bouguerche et al., 2019a, 2019b, 2019c, 2020; Kheddam et al., 2016, 2020), we collected representatives of a monogenean similar to $F$. ophidii on gills of $O$. barbatum. The specimens are described here and compared to original description of the species. A diagnosis of Flexophora is provided.

\section{Materials and methods}

Fishes

During 2016, 239 specimens of Ophidion barbatum were collected from Cherchell $\left(36^{\circ} 36^{\prime} 31^{\prime \prime} \mathrm{N}\right.$, $2^{\circ} 11^{\prime} 50$ ” E) off the Algerian coast of the Mediterranean. Fish specimens were transferred to the laboratory shortly after capture and identified using the keys of Fischer et al. (1987). Gills were removed from each fish and were observed under microscope for the presence of monogeneans.

\section{Monogeneans}

Monogeneans were removed alive from gills using fine dissection needles, then preserved in 70\% ethanol, stained with acetic carmine, dehydrated in an ethanol series (70, 96 and 100\%), cleared in clove oil, and mounted in Canada balsam. Drawings were made with the help of a Leitz microscope equipped with a drawing tube and scanned and redrawn on a computer with Adobe Illustrator (CS5). Measurements are in micrometres, and are given as the range followed by the mean \pm standard deviation if $n>30$ and the number of measurements in parentheses. The nomenclature of clamp sclerites proposed by Llewellyn (1958) and used by Prost \& Euzet (1962) for F. ophidii is adopted here.

\section{Family Diclidophoridae Cerfontaine, 1895 Genus Flexophora Prost \& Euzet, 1962}

\section{Flexophora ophidii Prost \& Euzet, 1962}

Type-host: Ophidion barbatum Linnaeus (Ophidiiformes: Ophidiidae), snake blenny.

Type-locality: off Sète, France.

Other locality: off Cherchell, Algerian coast (this paper).

Type-material: Muséum National dHistoire Naturelle, Paris, France, in the collection of Professor Louis Euzet (MNHN 306HG, Box 4, Slides 45-49, 4 slides marked as cotypes). Not examined due to COVID-19 lockdown in 2020.

Voucher material: Deposited in the collection of the Muséum National d'Histoire Naturelle, Paris (MNHN HEL1294-HEL1306).

Site on host: Gills.

\section{Description}

[Based on 37 specimens. Measurements in Table 1; Figs. 1-4).] Body small and stocky. A well-marked constriction delimiting the pre-pharynx zone present (Fig. 1). Haptor ovoid, symmetrical, with 2 rows of clamps. Clamps pedunculated (Fig. 1A), typically diclidophorid (Fig. 1C). Clamps asymmetrical, decreasing in size antero-posteriorly, with 2 opposable jaws (Fig. 4). Anterior jaw formed by median sclerite a3, marginal sclerites c1, c2, c3 and d1, d2, d3. Sclerite a3 large, dorsal to $\mathrm{c} 3$, expanding to a lamellate extension $b$. A narrow slit separating $b$ from peripheral sclerite c1. Median sclerites a1 and a2 absent. Proximally, $\mathrm{c} 1$ and $\mathrm{d} 1$ continuing with $\mathrm{c} 2$ and $\mathrm{d} 2$ which folds back ventrally to a3 forming $\mathrm{c} 3$ and $\mathrm{d} 3$. Sclerites $\mathrm{c} 1$ and $\mathrm{d} 1$ fused distally. Posterior jaw formed by median sclerite $f$, four marginal sclerites: $\mathrm{i}$ and k proximally; g1 and g2 distally. Sclerite f long, hollow for most of its length by a thin gutter. Sclerite $f$ $\mathrm{T}$-shaped at both ends; proximal $\mathrm{T}$ branches thin, distal branches wide. Marginal sclerites g1 and g2 approaching each other distally but unfused. Proximally, sclerites $\mathrm{i}$ and $\mathrm{k}$ articulated on $\mathrm{g} 1$ and $\mathrm{g} 2$ (Fig. 4).

Terminal lappet present (Fig. 1E), armed with two symmetrical pairs of anchors (Fig. 1D), dissimilar in shape and size: small, posteriormost anchor pair; large anteriormost anchor pair sickle-shaped.

Pair of oval prohaptoral suckers, muscular aseptate, with numerous small thorns. Pharynx subspherical, muscular and median (Fig. 2). Oesophagus median, 


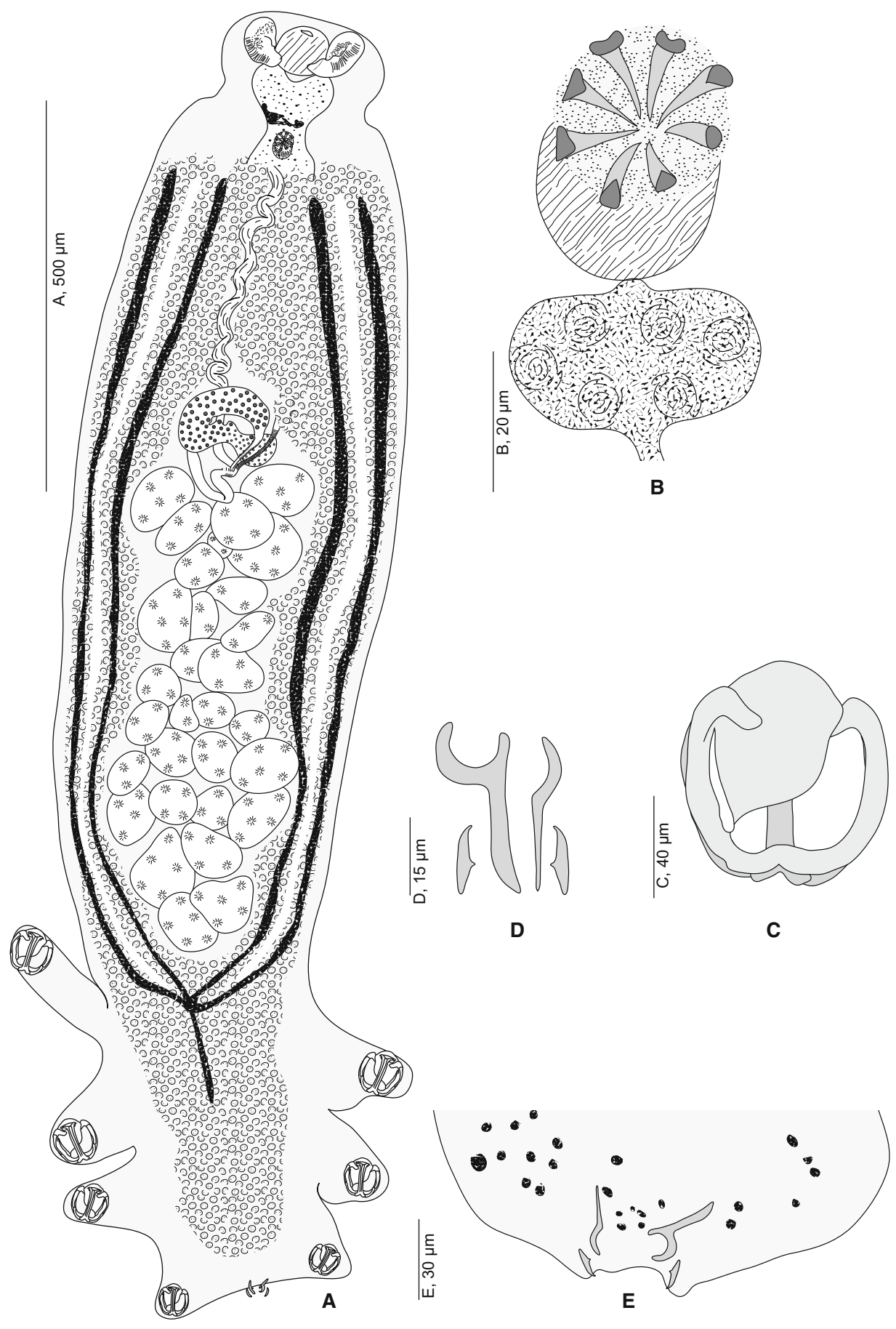

Fig. 1 Flexophora ophidii Prost \& Euzet, 1962 ex Ophidion barbatum. A, Whole body (MNHN HEL1294); B, Male copulatory organ (MNHN HEL1295); C, Clamp, dorsal view (MNHN HEL1296); D, Posterior lappet (MNHN HEL1298); E, Hooks and anchors of terminal lappet (MNHN HEL1298) 
Table 1 Measurements of Flexophora ophidii ex Ophidion barbatum from two localities in the Mediterranean

\begin{tabular}{|c|c|c|}
\hline $\begin{array}{l}\text { Locality } \\
\text { Source }\end{array}$ & $\begin{array}{l}\text { Off France } \\
(\mathrm{n}=8) \\
\text { Prost \& Euzet (1962) }\end{array}$ & $\begin{array}{l}\text { Off Algeria } \\
(\mathrm{n}=37) \\
\text { Present study }\end{array}$ \\
\hline Body length & $1,500-2,750$ & $1,453-2,247(1,896 \pm 79 ; \mathrm{n}=31)$ \\
\hline Body width & $400-850$ & $364-625(507 \pm 73 ; \mathrm{n}=31)$ \\
\hline Haptor length & & $343-765(543 \pm 140 ; \mathrm{n}=32)$ \\
\hline Total length & & $2,244-2,859(2,195 ; n=29)$ \\
\hline First pair of clamps length & $75-87$ & $80-88(85 ; \mathrm{n}=24)$ \\
\hline First pair of clamps width & $75-80$ & $74-85(82 ; n=24)$ \\
\hline Second pair of clamps length & $80-100$ & $67-96(86 ; n=22)$ \\
\hline Second pair of clamps width & $80-95$ & $67-85(76 ; n=22)$ \\
\hline Third pair of clamps length & $80-100$ & $78-92(76 ; n=24)$ \\
\hline Third pair of clamps width & $80-95$ & $64-83(73 ; n=24)$ \\
\hline Fourth pair of clamps length & $80-95$ & $65-79(75 ; \mathrm{n}=26)$ \\
\hline Fourth pair of clamps width & $80-100$ & $64-79(71 ; \mathrm{n}=26)$ \\
\hline Long anchor & 28 & $10-23(19 ; \mathrm{n}=15)$ \\
\hline Small anchor & & $5-10(8 ; \mathrm{n}=15)$ \\
\hline Prohaptoral suckers length & $80-95$ & $71-91(81 \pm 8 ; n=32)$ \\
\hline Prohaptoral suckers length & 45 & $46-82(65 \pm 12 ; n=32)$ \\
\hline Prohaptoral suckers length & $65-130$ & $66-123(109 \pm 18 ; \mathrm{n}=31)$ \\
\hline Pharynx width & $60-100$ & $57-123(102 \pm 21 ; \mathrm{n}=31)$ \\
\hline Genital atrium length & & $23-38(32 \pm 5 ; n=33)$ \\
\hline Genital atrium width & & $22-36(30 \pm 5 ; n=33)$ \\
\hline Distance genital atrium-anterior extremity & & 204-305 (265 $\pm 27 ; n=31)$ \\
\hline Testes number & $23-28$ & $22-26$ \\
\hline No. of atrial hooks & $6-8$ & 8 \\
\hline Atrial hooks length & & $7-10(9 ; \mathrm{n}=16)$ \\
\hline
\end{tabular}

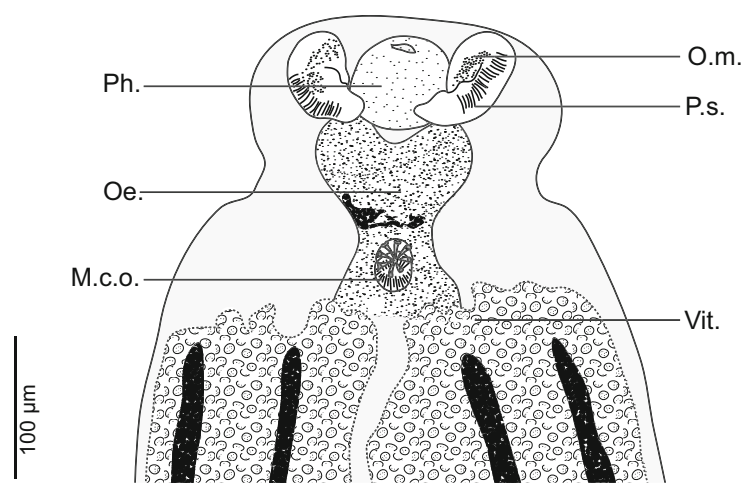

Fig. 2 Flexophora ophidii Prost \& Euzet, 1962 ex Ophidion barbatum. Anterior extremity showing relative positions of prohaptoral suckers, pharynx, and mal copulatory organ (MNHN HEL1294)

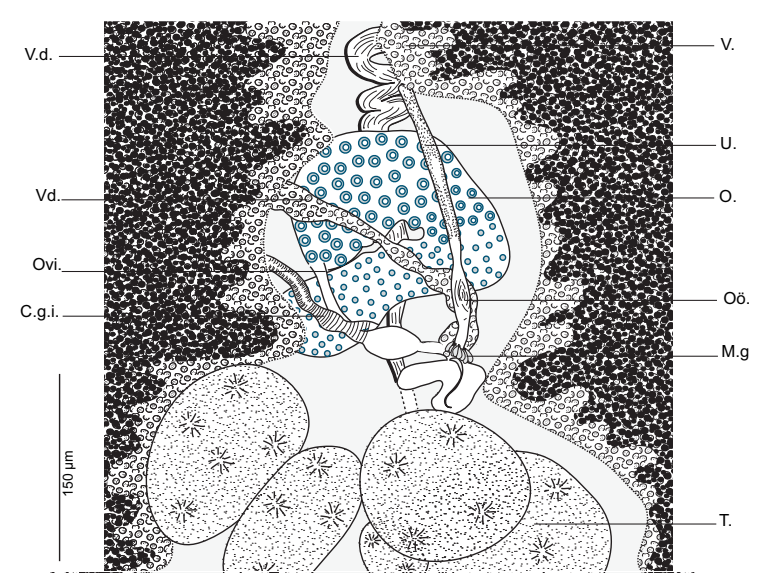

Fig. 3 Flexophora ophidii Prost \& Euzet, 1962 ex Ophidion barbatum. Detail of anatomy of reproductive organs in the region of ovary (MNHN HEL1296, 1297). Abbreviations: V.d., vas deferens; V.d., vitelloduct; Ovi., oviduct; C.g.i., genitointestinal canal; V., vitellarium; U., uterus; O., ovary; Oo., oötype; M.g., Mehlis'gland; T., testis 

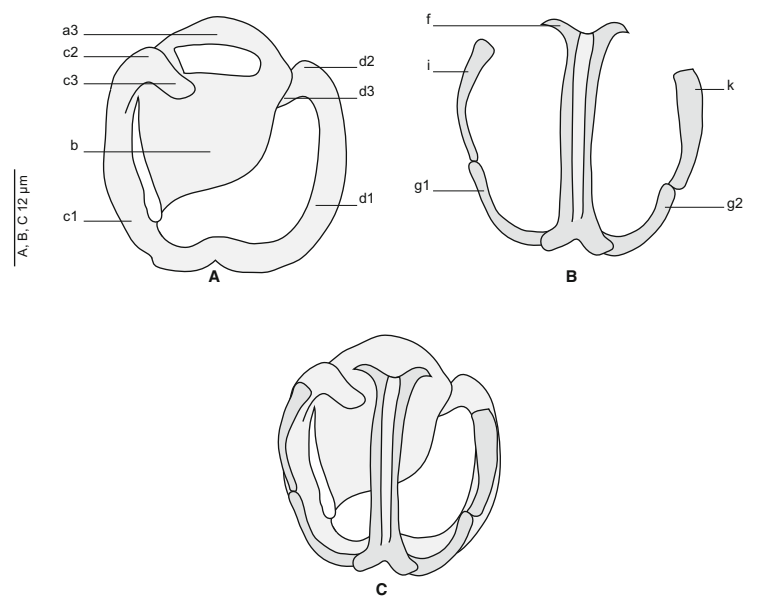

Fig. 4 Flexophora ophidii Prost \& Euzet, 1962 ex Ophidion barbatum. Clamp, figure with detailed legends (MNHN HEL 1296). A, Dorsal jaw; B, Ventral jaw; C, Whole clamp (ventral view)

voluminous and heart-shaped, bifurcated at level of genital atrium. Intestinal branches extending almost to posterior end of body, fusing in posterior part of body forming a peduncle extending up to middle third of haptor (Fig. 1A)

Testes numerous, postovarian, variously shaped, arranged irregularly in the posterior third of the body and confined to the intercrural field. Vas deferens large, conspicuous, running forward along body midline; at a level just anterior to the male copulatory organ (MCO), narrowing to a very short duct that swells to an ovoid mid-ventral prostatic vesicle (Fig. 1B). Prostatic vesicle communicating with genital atrium by short canaliculus. Genital pore dorsal, with muscular rim, armed with circle of 7-8 hooks. Atrial hooks with pointed bases; shafts with curved pointed tips directed inwards.

Ovary pretesticular, complex, beginning on right side of body; forms a loop on left side, returns parallel to right side where it narrows to form oviduct. Oviduct long, arising from distal end of ovary and opening into genito-intestinal canal. Oviduct forming a posterior loop then widening into an oötype surrounded at its base by Mehlis' gland. Uterus, originating from the oötype, runs forwards. Genito-intestinal canal, long, ribbed, originating from right intestinal branch, ventral to ovary (Fig. 3). Vitellarium follicular, coextensive with intestinal branches, extending from level of genital atrium to haptor, fused posterior to testes and extending to median region of haptor. Vitelline follicles confluent anteriorly, located between genital atrium and ovary. Transverse vitelloducts long, fusing in midline ventral to ovary, to form vitelline reservoir. Vagina absent.

Remarks

As previously mentioned, $F$. ophidii has never been redescribed neither reported since its original description by Prost \& Euzet (1962). The latter lacked a diagnosis of the genus which remains unavailable to date. After examination of an extensive material from the type-host, a diagnosis of the genus is proposed accordingly.

\section{Genus Flexophora Prost \& Euzet, 1962}

\section{Diagnosis}

Body small, stocky. Haptor not separated from body, ovoid, symmetrical, bearing 4 pairs of pedunculated clamps, arranged in 2 rows. Clamps typically diclidophorid, decreasing in size antero-posteriorly. Clamps asymmetrical with opposable dissimilar jaws; anterior jaw composed of 5 sclerites including 4 peripheral and 1 large median sclerite; posterior jaw composed of 7 sclerites including 2 median fused sclerites and 3 pairs of peripheral sclerites. Sclerite a absent; $\mathrm{b}$ and $\mathrm{c} 1$ fused distally; $\mathrm{a} 3$ and $\mathrm{b}$ covering approximately two thirds of the surface of posterior jaw. Terminal lappet present in posterior edge of haptor, with 2 symmetrical pairs of anchors, dissimilar in shape and size: small, posteriormost anchor pair; large anteriormost anchor pair sickle-shaped. Prohaptoral suckers paired, non-septate, with numerous small thorns. Pharynx present. Ceca diverticulated confluent posteriorly and extending into haptor. Testes numerous, postovarian. Copulatory organ armed with 6-8 curved hooks. Prostatic vesicle present. Ovary inverted C-shaped. Vitelloduct shifted from body midline. Genito-intestinal canal present. Seminal receptacle absent. Vagina absent. Parasites on gills of Ophidiidae.

Type-species: Flexophora ophidii Prost \& Euzet, 1962. 


\section{Discussion}

Based on the number and structure of clamps and organization of the MCO, the specimens collected from $O$. barbatum are members of Diclidophoridae. According to Prost \& Euzet (1962) who followed Sproston (1946), by having clamps that function as real clamps and not as suckers the specimens belong to the subfamily Diclidophorinae (Sproston, 1946; Prost $\&$ Euzet, 1962). The arrangement of the peripheral sclerites of clamps associate them to Flexophora.

The measurements of our specimens did not reveal any significant differences with $F$. ophidii, described by Prost \& Euzet (1962). We noted a smaller size of third and fourth pair of clamps and anchors in the specimens of the present study (Table 1), but measurements and counts overlap overall. These minor differences can be due to sampling effort and are likely to be corrected with additional samples from the typelocality, off France. The number of specimens studied in the original description was small, the authors collected a total of 8 specimens and did not mention whether they measured all of them.

Furthermore, our specimens collected from Ophidion barbatum off Algeria showed a morphoanatomy similar to that of $F$. ophidii. However, we have highlighted the presence of a constriction at the level of the pharynx in the anterior part and an additional pair of hamuli at the level of the terminal lappet in our specimens. These two features were neither mentioned nor illustrated in the original description. However, the morphological differences highlighted are subtle and cannot be used to differentiate a new species. Hence, with such high resemblances and overlaps in measurements and counts, diclidophorids from Ophidion barbatum from off Algeria are considered conspecific with $F$. ophidii.

Acknowledgements Our thanks are due to fishermen from Bouharoun especially Mohamed Kayrouze. This research was supported by Direction Générale de la Recherche Scientifique et du Développement Technologique (DGRSDT, Algiers, Algeria), by Institut de Systématique, Évolution, Biodiversité (ISYEB, MNHN, Paris, France), and by the DeepBlue Project: Distance Crossborder Traineeship Programme co-financed by "The European Maritime and Fisheries Fund (EMFF)".

\section{Compliance with ethical standards}

Conflict of interest The authors declare that they have no conflict of interest.
Ethical approval All applicable institutional, national and international guidelines for the care and use of animals were followed.

\section{References}

Ayadi, Z. E. M., Gey, D., Justine, J.-L., \& Tazerouti, F. (2017). A new species of Microcotyle (Monogenea: Microcotylidae) from Scorpaena notata (Teleostei: Scorpaenidae) in the Mediterranean Sea. Parasitology International, 66, 37-42.

Bouguerche, C., Gey, D., Justine, J.-L., \& Tazerouti, F. (2019a). Microcotyle visa $\mathrm{n}$. sp. (Monogenea: Microcotylidae), a gill parasite of Pagrus caeruleostictus (Valenciennes) (Teleostei: Sparidae) off the Algerian coast, Western Mediterranean. Systematic Parasitology, 96, 131-147.

Bouguerche, C., Gey, D., Justine, J.-L., \& Tazerouti, F. (2019b). Towards the resolution of the Microcotyle erythrini species complex: description of Microcotyle isyebi n. sp. (Monogenea, Microcotylidae) from Boops boops (Teleostei, Sparidae) off the Algerian coast. Parasitology Research, $118,1417-1428$.

Bouguerche, C., Tazerouti, F., Gey, D., \& Justine, J.-L. (2019c). Redescription and molecular characterisation of Allogastrocotyle bivaginalis Nasir \& Fuentes Zambrano, 1983 (Monogenea: Gastrocotylidae) from Trachurus picturatus (Bowdich) (Perciformes: Carangidae) off the Algerian coast, Mediterranean Sea. Systematic Parasitology, 96, 681-694.

Bouguerche, C., Tazerouti, F., Gey, D., \& Justine, J.-L. (2020). No vagina, one vagina, or multiple vaginae? An integrative study of Pseudaxine trachuri (Monogenea, Gastrocotylidae) leads to a better understanding of the systematics of Pseudaxine and related genera. Parasite, 27, 50.

Chaabane, A., Justine, J.-L., Gey, D., Bakenhaster, M. D., \& Neifar, L. (2016a). Pseudorhabdosynochus sulamericanus (Monogenea, Diplectanidae), a parasite of deep-sea groupers (Serranidae) occurs transatlantically on three congeneric hosts (Hyporthodus spp.), one from the Mediterranean Sea and two from the western Atlantic. PeerJ, 4, e2233.

Chaabane, A., Neifar, L., Gey, D., \& Justine, J.-L. (2016b). Species of Pseudorhabdosynochus (Monogenea, Diplectanidae) from groupers (Mycteroperca spp., Epinephelidae) in the Mediterranean and Eastern Atlantic Ocean, with special reference to the "beverleyburtonae group" and description of two new species. PLOS ONE, 11, e0159886.

Chaabane, A., Neifar, L., \& Justine, J.-L. (2015). Pseudorhabdosynochus regius $\mathrm{n}$. sp. (Monogenea, Diplectanidae) from the mottled grouper Mycteroperca rubra (Teleostei) in the Mediterranean Sea and Eastern Atlantic. Parasite, 22, 9.

Cruces, C. L., Chero, J. D., Sáez, D., Iannacone, J., \& Luque, J. L. (2017). Olivacotyle hemanthiasi n. gen. n. sp. (Monogenea: diclidophoridae) from the gills of damsel bass $\mathrm{He}$ manthias signifer (garman, 1899) (teleostei: serranidae) in the South American Pacific Ocean. Neotropical Helminthology, 11, 387-394.

Derouiche, I., Neifar, L., Gey, D., Justine, J.-L., \& Tazerouti, F. (2019). Holocephalocotyle monstrosae n. gen. n. sp. 
(Monogenea, Monocotylidae) from the olfactory rosette of the rabbit fish, Chimaera monstrosa (Holocephali, Chimaeridae) in deep waters off Algeria. Parasite, 26, 59.

Dillon, W. A., \& Hargis, W. J. (1965). Monogenetic trematodes from the Southern Pacific Ocean. 2. Polyopisthocotyleids from New Zealand fishes: the families Discocotylidae, Microcotylidae, Axinidae and Gastrocotylidae. Biology of the Antarctic Seas II, Antarctic Research Series, 5, 251-280.

Euzet, L., Combes, C., \& Caro, C. (1993) A check list of Monogenea of mediterranean fish. In: Second International Symposium on Monogenea, Montpellier/Sète, 1993.

Fischer, W., Bauchot, M.-L., \& Schneider, M. (1987). Fiches FAO d'identification des espèces pour les besoins de la pêche. (Révision 1). Méditerranée et mer Noire. Zone de pêche 37. Volume II. Vertébrés. Publication préparée par la FAO, résultat d'un accord entre la FAO et la Commission des Communautés Européennes (Projet GCP/INT/422/ EEC) financée conjointement par ces deux organisations, Vo1. 2. Rome: FAO, 761-1530.

Kheddam, H., Chisholm, L. A., \& Tazerouti, F. (2020). Septitrema lichae n. g., n. sp. (Monogenea: Monocotylidae) from the nasal tissues of the deep-sea kitefin shark, Dalatias licha (Squaliformes: Dalatiidae), off Algeria. Systematic Parasitology, https://doi.org/10.1007/s11230-02009942-4.

Kheddam, H., Justine, J.-L., \& Tazerouti, F. (2016). Hexabothriid monogeneans from the gills of deep-sea sharks off Algeria, with the description of Squalonchocotyle euzeti n. sp. (Hexabothriidae) from the kitefin shark Dalatias licha (Euselachii, Dalatiidae). Helminthologia, 53, 354-362.

Krøyer, H. N. (1838). Danmarks fiske. Vol. I.: Kjobenhavn.

Mamaev, Iu L, Mordvinova, T. N., \& Parukhin, A. M. (1985). Monogeneans of the genus Polyipnicola (Diclidophoridae). Vestnik Zoologii, 5, 8-14. (in Russian).

Mamaev, Y. L. (1976). The system and phylogeny of monogeneans of the family Diclidophoridae. Proc. Inst. Biol. Pedol. Far-East Sci. Center, Adad. Sci. USSR, New Ser., 35, 57-80.

Moravec, F., Chaabane, A., Neifar, L., Gey, D., \& Justine, J. L. (2016). Descriptions of Philometra aenei n. sp. and P. tunisiensis n. sp. (Nematoda: Philometridae) from Epinephelus spp. off Tunisia confirm a high degree of host specificity of gonad-infecting species of Philometra in groupers (Serranidae). Systematic Parasitology, 93, $115-128$.

Payne, R. (1986). Lampanyctophilus wisneri gen. et sp. n. (Monogenea: Diclidophoridae), a gill parasite of Lampanyctus ritteri (Myctophidae) from the eastern Pacific and an emended description of Myctophiphilus sprostonae (Martin, 1973) comb. n. Proceedings of the Helminthological Society of Washington, 53, 157-161.

Price, E. W. (1943). North American monogenetic trematodes: VI. The family Diclidophoridae (Diclidophoroidea). Journal of the Washington Academy of Sciences, 33, 44-54.

Prost, M., \& Euzet, L. (1962). Flexophora ophidii ngn sp. un Diclidophoridae (Monogenea) parasite d'Ophidium barbatum (L.) (Teleostei). Annales de Parasitologie Humaine et Comparée, 37, 210-215.

Rohde, K., \& Williams, A. (1987). Taxonomy of monogeneans of deep sea fishes in southeastern Australia. Systematic Parasitology, 10, 45-71.

Rubec, L. (1991). Mamaevodiclidophora nom. nov. proposed for Neodiclidophora Mamaëv, 1987, with a redescription of Mamaevodiclidophora pugetensis (Robinson, 1961) comb. nov. (Monogenea: Diclidophoridae). Canadian Journal of Zoology, 69, 873-875.

Rubec, L. A., \& Dronen, N. O. (1994). Revision of the genus Diclidophora Krøyer, 1838 (Monogenea: Diclidophoridae), with the proposal of Macrouridophora n. g. Systematic Parasitology, 28, 159-185.

Sproston, N. (1946). A synopsis of the monogenetic trematodes. Transactions of the Zoological Society of London, 25, 185-600.

Unnithan, R. V. (1966). Four new diclidophorids (Monogenoidea) parasitic on the gills of marine fishes from the southwest coast of India. Pacific Science, 20, 79-90.

Yamaguti, S. (1958). Studies on the helminth fauna of Japan. Part 53. Trematodes of fishes, XII. Publications of the Seto Marine Biological Laboratory, 7, 53-88.

Zhukov, E., \& Mamaev, Y. L. (1985). A new member of high monogeneans from gills of Synodus foetens from the Gulf of Mexico. Parazitologiya, 19, 250-253.

Publisher's Note Springer Nature remains neutral with regard to jurisdictional claims in published maps and institutional affiliations. 